\title{
CITY BRANDING SAIL TO INDONESIA 2019 DI PULAU BAWEAN SEBAGAI UPAYA MENINGKATKAN KUNJUNGAN WISATAWAN
}

\author{
Reza Arfiyan, Anam Miftakhul Huda \\ Universitas Negeri Surabaya
}

\begin{abstract}
Sail to Indonesia 2019 in Bawean Island is a program implemented by the Indonesian Ministry of Tourism in collaboration with yacht rally organizer from New Zealand. Sail to Indonesia has the purpose to develop tourism sector, especially maritime tourism in the area that is the path and center of Sail to Indonesia. Sail to Indonesia 2019, Yachters sailed in 10 places in Indonesia for three months, one of that in Bawean Island and Bawean Island became the only place in East Java which was visited by the Yachters. This research uses descriptive qualitative method that aims to analyze and determine the formation of the Sail to Indonesia 2019 image on Bawean Island as an effort to increase tourist visits. The results of this study concluded that the Department of Tourism \& Culture of Gresik in forming the image of Bawean Island not only applied the theory of uniqueness of events according to Getz such as hospitality, symboliysm, authenticity, theming, and festive spirit, but also there is an element of convenience. Department of Tourism \& Culture of Gresik did efforts to increasing tourist visits are by using wish images to maximize expectations of Bawean Island so as to provide the best service during activities. In addition, through the current image, tourists will tell all their best experiences and memories while on Bawean Island with word of mouth marketing.
\end{abstract}

\author{
Keywords \\ City Branding, Sail to Indonesia \\ 2019 in Bawean Island, \\ Image \\ Correspondence Contact \\ rezaarfiyan I 604 I 18408@mh \\ s.unesa.ac.id
}

\section{PENDAHULUAN}

Sail to Indonesia merupakan program yang dilaksanakan oleh Kementerian Pariwisata RI bekerjasama dengan yacht rally organizer dari Selandia Baru dengan total jumlah yacht yang berlabuh sebanyak 51 yacht dari 13 negara yang diikuti oleh 135 yachters. Sail to Indonesia mempunyai tujuan untuk mengembangkan sektor pariwisata, terutama sektor destinasi wisata bahari di daerah yang menjadi lintasan dan pusat Sail to Indonesia.

Sail to Indonesia 2019, para yachters berlayar di 10 tempat yang ada di Indonesia selama tiga bulan, salah satunya adalah di Pulau Bawean dan Pulau Bawean menjadi satu-satunya tempat di Jawa Timur. Pada tanggal 3-6 Oktober 2019, Pulau Bawean menjadi salah satu tuan rumah acara Sail to Indonesia 2019 yang diselenggarakan oleh Dinas Pariwisata dan Kebudayaan Kabupaten Gresik yang bekerja sama dengan Kementerian Pariwisata RI dan Kemenko Maritim RI. Sail to Indonesia 2019 di Pulau Bawean merupakan salah satu langkah yang digunakan oleh pemerintah Kabupaten Gresik melalui Dinas Pariwisata dan Kebudayaan Kabupaten Gresik untuk terus mempromosikan pariwisata alam bahari dan pariwisata budaya yang ada di Pulau Bawean kepada semua orang, terutama wisatawan mancanegara untuk menambah jumlah kunjungan wisatawan.

Adanya Sail to Indonesia 2019 di Pulau Bawean dijadikan pemerintah Kabupaten Gresik melalui Dinas Pariwisata dan Kebudayaan Kabupaten Gresik sebagai city branding Pulau Bawean untuk meningkatkan jumlah kunjungan wisatawan ke Pulau Bawean karena Pulau Bawean dianggap memiliki potensi untuk dijadikan sebagai destinasi wisata internasional. 
Penelitian (Astuti \& Kusumawati, 2018) yang berjudul "Upaya Pemasaran Pariwisata Ponorogo Melalui City Branding Dalam Meningkatkan Kunjungan Wisatawan" yang membahas penerapan city branding Kabupaten Ponorogo sebagai upaya pemasaran pariwisata melalui potensi seninya dengan penggunaan tagline "Ethnic Art of East Java". Hasilnya city branding telah menghasilkan peningkatan wisatawan, baik dari sisi kualitas pariwisata maupun kuantitas wisatawan.

Penelitian dengan konsep yang sama dari (Pakarti et al., 2017) dengan judul "Pengaruh City Branding Dan Event Pariwisata Terhadap Keputusan Berkunjung Serta Dampaknya Pada Minat Berkunjung Kembali Ke Kabupaten Banyuwangi". Hasil dari penelitian ini menyimpulkan bahwa City branding berpengaruh terhadap minat berkunjung kembali Kabupaten Banyuwangi. Dalam penelitian tersebut city branding dijadikan sebagai alat promosi untuk meningkatkan kunjungan wisatawan, mengembangkan event pariwisata, meningkatkan perekonomian, serta memperkenalkan budaya.

Adanya penelitian-penelitian tersebut membuat peneliti tertarik untuk meneliti image yang dibentuk event pariwisata Sail to Indonesia 2019 di Pulau Bawean Kabupaten Gresik yang merupakan city branding Pulau Bawean sebagai upaya untuk meningkatkan kunjungan wisatawan terutama wisatawan manacanegara. Dalam penelitian terdahulu tersebut membahas peran city branding dalam meningkatkan kunjungan wisatawan, sedangkan pada penelitian ini akan menganalisis citra Pulau Bawean selama kegiatan Sail to Indonesia 2019. Berdasarkan pemaparan di atas rumusan masalah dalam penelitian ini yaitu Bagaimana image komunikasi pariwisata yang dibentuk event pariwisata Sail to Indonesia 2019 di Pulau Bawean Kabupaten Gresik yang merupakan city branding Pulau?

\section{KAJIAN TEORITIK}

\section{Komunikasi Pariwisata}

Menurut Pendit (2006:31) komunikasi pariwisata adalah gabungan antara gejala dan hubungan yang timbul dari interaksi wisatawan, bisnis, pemerintah daerah serta masyarakat yang menjadi tuan rumah dalam proses menarik dan melayani wisatawan-wisatawan serta para pengunjung lainya.

Menyatunya beberapa disiplin ilmu di dalam satu kajian tentang komunikasi dan pariwisata melahirkan konsep yang disebut dengan komunikasi pariwisata. Kajian komunikasi pariwisata memiliki kedekatan biologis dengan kajian-kajian komunikasi dan pariwisata yang melahirkanya. Komunikasi menyumbangkan teori-teori komunikasi persuasif, teori komunikasi massa, teori komunikasi interpersonal dan kelompok. Sementara pariwisata menyumbangkan field kajian pemasaran pariwisata, destinasi pariwisata, aksesibilitas ke destinasi dan SDM serta kelembagaan kepariwisataan (Bungin, 2015:92).

Bidang-bidang kajian utama dalam kajian komunikasi pariwisata menurut Bungin (2015:94) adalah sebagai berikut:

1. Komunikasi Pemasaran Pariwisata

2. Brand Destinasi

3. Manajemen Komunikasi Pariwisata

4. Komunikasi Transportasi Pariwisata

5. Komunikasi Visual Pariwisata

6. Komunikasi Kelompok Pariwisata

7. Komunikasi Online Pariwisata

8. Public Relations dan MICE 


\section{Riset Komunikasi Parwisata}

\section{Event Marketing}

Menurut Getz (2008:404) event adalah sesuatu yang terjadi, kejadian, sebagai suatu hasil atau bagian dari berbagai kegiatan. Menurut Noor (2009:90) event adalah sebagai suatu kegiatan yang diselenggarakan untuk memperingati hal-hal penting, baik secara individu atau kelompok. Event adalah suatu atraksi yang bisa berupa tradisi, olahraga, budaya, ritual agama, dan perayaan tertentu. Event marketing dalam kajian komunikasi pariwisata masuk dalam kajian utama yaitu kajian komunikasi visual pariwisata dan komunikasi kelompok pariwistaa dimana didalamnya dijelaskan bahwa bisnis pariwisata bukan merupakan bisnis personal, sehingga keterampilan komunikasi kelompok dianggap penting. Hal ini dapat dijalankan dengan menyelenggarakan sebuah event dan mengembangkan komunikasi visual pariwisata dalam bidang desain grafis karna bidang ini akan terus berkembang kedepannya (Bungin, 2015:94).

Menurut (Donalds Getz) faktor-faktor yang berkontribusi dalam membuat event menjadi spesial yaitu uniqueness (unik) yang mencakup dari elemen gaya seperti hospitality (keramah tamahan), symbolism (simbol), festive spirit (suasana meriah), theming (tema), dan authenticity (autentik).

Hospitality, peneliti berfokus pada keramah tamahan yang dimiliki oleh masyarakat Pulau Bawean dan keramah tamahan penanggung jawab kegiatan yakni Dinas Pariwisata dan Kebudayaan Kabupaten Gresik selama Sail to Indonesia 2019 yang akan berdampak terhadap pembentukan image Sail to Indonesia 2019.

Symbolism, peneliti akan berokus pada penggunaan simbol-simbol, budaya dan tradisi mengenai Pulau Bawean yang digunakan selama Sail to Indonesia 2019 yang berguna untuk memudahkan wisatawan dalam mendapatkan tujuan dan makna dari penyelenggaraan acara serta simbol-simbol untuk memeriahkan acara Sail to Indonesia 2019 di Pulau Bawean.

Festive Spirit, peneliti akan melakukan penelitian sesuatu hal yang membuat penyelenggaraan Sail to Indonesia 2019 menjadi lebih meriah. Konsep dan kemasan acara Sail to Indonesia 2019 yang baik akan menjadi daya tarik tersendiri selama Sail to Indonesia 2019.

Theming, pemilihan gambaran tema dalam penyelenggaraan Sail to Indonesia 2019 yang bertujuan untuk pengimplementasian tradisi, keaslian budaya Bawean, suasana meriah, serta interaksi dan pelayanan dengan baik masyarakat. Selain itu, pemilihan tema juga akan berpengaruh selama penyelenggaraan acara.

Authenticity, keaslian budaya dan tradisi Pulau Bawean yang disuguhkan selama Sail to Indonesia 2019 akan menunjukkan keaslian dari tradisi dan budaya yang dimiliki oleh Pulau Bawean untuk menjaga nilai budaya dan adat Pulau Bawean dan juga bisa menjada daya tarik perhatian wisatawan.

Teori keunikan sebuah event menurut Getz dengan lima unsur keunikannya yaitu hospitality (keramah tamahan), symbolism (simbol), festive spirit (suasana meriah), theming (tema), dan authenticity (autentik), peneliti akan menemukan data-data dari narasumber atrau informan yang telah dipilih dan kemudian menyimpulkan image yang terbentuk dari adanya Sail to Indonesia 2019 sebagai upaya meningkatkan kunjungan wisatawan ke Pulau Bawean. Selain itu, peneliti juga akan menganalisis unsur serta jenis image yang digunakan oleh pelaksana selama Sail to Indonesia 2019 di Pulau Bawean.

\section{METODOLOGI}

Penelitian ini menggunakan jenis metode penelitian deskriptif kualitatif dengan menggunakan pendekatan studi kasus dengan metode analisis deskriptif yang mencakup 
observasi, wawancara, studi dokumentasi, dan analisis data. Objek dalam penelitian ini adalah Sail to Indonesia 2019 di Pulau Bawean. Penelitian ini telah dilakukan pada tanggal 30 Maret 2020 hingga tanggal 30 April 2020. Informan yang menjadi subjek penelitian ini adalah Kepala Bidang Pemasaran Pariwisata Disparbud Gresik, Penanggung jawab Sail to Indonesia 2019 di Pulau Bawean, Ketua Paguyuban Duta Wisata Cak Yuk Kabupaten Gresik, Owner Mekar Padu selaku agen travel Bawean dan Masyarakat Bawean sekaligus anggota Pokdarwis.

Penelitian ini menggunakan tiga teknik analisis data yaitu pemrosesan satuan data, menandai kata kunci serta menemukan gagasan dan tahap kategorisasi data. Sedangkan teknik uji keabsahan menggunakan triangulasi teknik dan triangulasi sumber.

\section{HASIL DAN PEMBAHASAN}

\section{Implementasi Sail to Indonesia 2019 di Pulau Bawean}

Pembentukan image Pulau Bawean sebagai tempat destinasi wisata ramah dapat disimpulkan bahwa keramahan yang diusung selama Sail to Indonesia 2019 di Pulau Bawean yaitu dengan memberikan sambutan dan pelayanan terbaik selama kegiatan. Namun selain itu, sikap dan perilaku masyarakat Bawean juga menjadi salah satu fokus keramahan seperti saling menyapa, menebar senyum, membantu apa yang dibutuhkan serta rasa saling menghormati dan menghargai.

"Masyarakat Bawean menganggap bahwa tamu itu merupakan kakak tertua dari sebrang. Jadi wajib untuk dihormati, kalau istilah umumya tamu adalah raja ya miripmirip seperti itu, intinya bahwa masyarakat lokal bawean sangat menghormati tamu dan juga merasa wajib untuk melayani tamu tersebut dalam rangka pemenuhan kebutuhan selama yang ada di Bawean." (Sumber: wawancara dengan penanggung pawab Sail to Indonesia 2019, 18 Maret 2020).

"Masyarakat Bawean memang sudah dikenal dengan keramahannya. Keramahan masyarakat Bawean itu dengan menganggap para wisatawan seperti saudara sendiri. Dengan begitu, wisatawan akan nyaman di Pulau Bawean dan akan datang kembali." (Sumber: wawancara dengan masyarakat Bawean, 3 April 2020)

Adanya hal tersebut akan menimbulkan citra yang positif yang memberikan wisatawan rasa nyaman selama ada di Pulau Bawean karena perilaku masyarakatnya. Hal tersebut bisa menjadikan image yang baik dan Pulau Bawean dikenal sebagai Wisata Ramah. Hal ini sesuai dengan pengertian komunikasi pariwisata menurut Pendit (2006:31) hubungan yang timbul dari interaksi wisatawan, bisnis, pemerintah daerah serta masyarakat yang menjadi tuan rumah dalam proses menarik dan melayani wisatawan.

Penggunaan simbol-simbol untuk membentuk sebuah image selama Sail to Indonesia 2019 di Pulau Bawean mengartikan bahwa penyelenggara ingin menunjukkan potensi wisata alam dan bahari serta atraksi budaya Pulau Bawean yang tersirat dalam atribut-atribut yang digunakan selama kegiatan.

"Kalau dikaitkan dengan semiotik ya ingin menunjukkan kearifan lokal Bawean dengan cara yang tersirat." (Sumber: wawancara dengan Kepala Bidang Pemasaran Disparbud Gresik, 7 April 2020).

Kemeriahan Sail to Indonesia 2019 di Pulau Bawean merupakan hasil dari ide dan pikiran panitia penyelenggara. Kemeriahan selama acara bertujuan untuk membentuk sebuah image yang positif dimata para wisatawan bahwa selama mereka di Bawean mereka diberikan pelayanan terbaik dengan disuguhkan konsep dan acara yang menarik dan luar biasa. Hal tersebut berarti penyelenggara tidak main-main dalam menyelenggarakan event internasional. Dapat disimpulkan bahwa konsep dan kemasan stage performance selama 
kegiatan berlangsung bertujuan untuk membawa wisatawan dalam suasana Bawean dengan menampilkan atraksi budaya Bawean.

Menurut (Lestari et al., 2017) bahwa tema sebuah event adalah salah satu hal yang mempengaruhi citra destinasi wisata. Oleh karena itu, dapat disimpulkan bahwa Disparbud Gresik membuat tema acara yang menunjukkan bahwa acara tersebut mengandung unsur Bawean sekali. Unsur Bawean dimunculkan dari konsep dan kemasan acara, penggunan atribut-atribut selama acara, penampilan-penampilan, serta pelayanan wisatawan selama acara berlangsung. Dari penggunaan tema diatas, Disparbud Gresik selaku penyelenggara ingin menunjukkan image bahwa Bawean ini merupakan sebuah Pulau Kecil yang terdapat paket wisata lengkap didalamnya baik beragam wisata alam, wisata religi, wisata flora dan fauna, wisata kuliner serta atraksi budaya dan kesenian Pulau Bawean.

"Tahapan perumusannya tema ya dari musyawarah bersama atau FGD oleh stakeholders terkait itu tadi baik pemerintah ataupun non pemerintah yang dalam hal ini ada komunitas dan juga masyarakat. Kebetulan juga disitu ada peran kerukunan masyarakat bawean, itu ada juga yang merupaka saudagar-saudagar atau tokoh-tokoh bawean yang ada di mancanegara seperti Singapura dan Malaysia mereka turut andil dalam membantu perumusan tema melalui usulanusulan." (Sumber: wawancara dengan penanggung pawab Sail to Indonesia 2019, 18 Maret 2020).

Produk-produk budaya asli yang ditonjolkan selama Sail to Indonesia 2019 di Pulau Bawean ini berkesan menunjukkan image bahwa di pulau kecil seperti Bawean terdapat sejarah yang diiringi dengan beragamnya produk budaya asli dari Bawean yang merupakan hasil akulturasi budaya dari berbagai suku yang ada di Indonesia.

"Jadi produk-produk budaya yang ditampilkan merupakan budaya lokal bawean, dikarenakan kita memang ingin konsentrasi pada lokus dimana kegiatan itu berlangsung maka kita lebih menitik beratkan pada performance penampilan budaya bawean dimana Bawean ini terbentuk karena adanya akulturasi budaya suku yang ada di Indonesia dan memang tujuan dari kegiatan tersebut adalah memang ingin mengangkat potensi wisata di bawean." (Sumber: wawancara dengan Kepala Bidang Pemasaran Disparbud Gresik, 7 April 2020).

Adanya pengimplementasian kelima unsur teori keunikan event menurut Getz, dapat disimpulkan seperti apa image yang dibentuk oleh Disparbud Gresik. Sesuai dengan penelitian (Jani, 2016) bahwa image yang terbentuk melalui event pagelaran seni di Anjungan Jawa Timur dikarenakan adanya unsur uniqueness, festive spirit, authenticity, quality, hospitality, theming, symbolism, tradition yang berpengaruh dengan keputusan berkunjung wisatawan untuk datang ke tempat wisata.

Peneliti dalam menganalisis pembentukan sebuah image tempat wisata melalui sebuah event Sail to Indonesia 2019 di Pulau Bawean menyatakan bahwa Disparbud tidak hanya menerapkan kelima unsur teori keunikan event menurut Donald Getz saja. Namun ada unsur lainnya dalam membentuk sebuah image selama kegiatan Sail to Indonesia 2019 di Pulau Bawean berlangsung. Unsur yang ditemukan oleh peneliti yaitu unsur kenyamanan (convinience).

Unsur kenyamanan (convinience) yang dilakasanakan oleh Disparbud dalam membentuk sebuah image kenyamanan yaitu dengan adanya pembuatan aplikasi berbasis internet bernama SIPATU GT yang berguna sebagai pusat layanan informasi mengenai Pulau Bawean untuk memudahkan para wisatawan dalam mengakses informasi Pulau Bawean. Selain itu, keseriusan dalam pemilihan tempat yang dekat dengan area yachters, kebersihan tempat, fasilitas tempat dan aspek pendukung lainnya seperti Mombhul Beach yang dekat area penangkaran rusa bawean. Seperti teori yang dikemukakan dalam (Ningsih, 2019) bahwa 
fasilitas di tempat wisata berfungsi untuk membantu kebutuhan wisatawan selama tinggal di daerah yang dikunjungi, termasuk didalamnya terdapat akomodasi wisatawan.

Unsur kenyamanan lainnya yaitu dengan adanya konsep dan kemasan acara yang mengajak para wisatawan untuk terlibat dalam acara berlangsung. Para wisatawan tidak hanya berperan sebagai penonton pasif saja, namun juga diajak dalam setiap bagian selama acara. Unsur kenyamanan yang diimplementasikan tersebut, membuat image Pulau Bawean menjadi positif sehingga para wisatawan merasa nyaman selama ada di Pulau Bawean dan terbentuk sebuah kenangan dan pengalaman yang baik.

Hal tersebut sesuai dengan yang dikatakan (Bowdin, 2011) bahwa convenience (kenyamanan) menjadi salah satu atribut yang membuat event menjadi spesial yang berdampak pada event itu sendiri. Selain itu, (Aurellia Frida, 2014) mengatakan bahwa kesan kenyamanan dalam event dapat meningkatkan kepercayaan antar satu sama lain.

\section{Proses Pembentukan Image Sail To Indonesia 2019 Di Pulau Bawean}

Proses pembentukan image Sail to Indonesia 2019 di Pulau Bawean, merupakan hasil sebuah ide dan pikiran dari Pemerintah Kabupaten Gresik melalui Disparbud Gresik dengan para stakeholders yang berlandaskan pada tujuannya yaitu selain memasarkan potensi wisatanya, namun juga sebagai usaha untuk meningkatkan jumlah pengunjung. Hal tersebut dikarenakan Pulau Bawean masih belum dikenal banyak orang, padahal potensi wisata alam di Pulau Bawean tidak kalah dengan wisata lainnya.

Komunikasi yang digunakan didalam pemerintahan Kabupaten Gresik dalam mempersiapkan Sail to Indonesia 2019 di Pulau Bawean untuk membentuk sebuah image positif Pulau Bawean, sejalan dengan komunikasi internal organisasi menurut (Effendy, 2007) yakni komunikasi atasan ke bawahan (vertikal up to down communication), komunikasi bawahan ke atasan (vertikal down to up communication) dan komunikasi sesama jabatan (horizontal communication). Komunikasi atasan ke bawahan (vertikal up to down communication) dilakukan oleh Bupati Gresik kepada Kepala Disparbud Gresik untuk menangani acara Sail to Indonesia 2019 di Pulau Bawean. Pada komunikasi bawahan ke atasan dari para Kepala Dinas kepada Bupati berlangsung saat rapat persiapan yang berupa usulan ide, konsep, dan kemasan kegiatan. Komunikasi sesama jabatan (horizontal communication) berlangsung pada koordinasi antara Kepala Disparbud dengan Kepala Kedinasan Gresik terkait untuk menyesuaikan kebutuhan sesuai tupoksinya.

Komunikasi pemerintah Gresik dengan pihak eksternal dimulai oleh Disparbud Gresik yang menyelenggarakan pertemuan dengan para stakeholders. Serta komunikasi eksternal antara Bupati Gresik dengan pihak penyelenggara pusat Kementerian Pariwisata RI. Perencanaan Sail to Indonesia 2019 di Pulau Bawean sebagai event promosi yang mengangkat kearifan lokal Pulau Bawean telah disepakati Kementerian Pariwisata RI sebagai hasil dari komunikasi yang telah dilakukan.

Hasil penelitian menyimpulkan bahwa unsur image yang dibentuk Disparbud Gresik dalam Sail to Indonesia 2019 di Pulau Bawean ini merupakan unsur citra positif dengan jenis wish image dan current image.

Wish image atau citra harapan adalah suatu citra yang diharapkan oleh pihak instansi. Citra ini tidak sama dengan citra yang sebenarnya. Biasanya citra harapan lebih menyenangkan dari pada citra yang ada walaupun dalam kondisi tertentu, citra yang terlalu baik juga bisa merepotkan.

Disparbud Gresik dalam membentuk sebuah citra harapan Sail to Indonesia 2019 di Pulau Bawean tentunya dengan memastikan semua aspek layanan disegala sisi pendukung acara sudah tersedia dengan baik. Selain sisi potensi wisata yang dimaksimalkan, Disparbud juga mempersiapkan dari sisi SDM yaitu dengan melakukan sosialisasi pendekatan kepada 
masyarakat Bawean bahwa akan ada event internasional di Pulau Bawean sehingga masyarakat nantinya sudah siap dan bisa menerima para wisatawan asing. Hal tersebut sudah terbukti bahwa masyarakat Bawean bisa menerima para wisatawan untuk tinggal bersama dalam beberapa hari.

Current image atau Citra yang Berlaku merupakan citra yang berkaitan dengan word of mouth yang berarti informasi yang diperoleh dari pengaruh orang lain. current image berkaitan dengan adanya pengalaman seseorang mengenai suatu tempat, yang kemudian pengalaman kemudian diceritakan kepada orang lain. Hal tersebut tidak akan menjadi sebuah masalah ketika yang diceritakan adalah hal yang positif mengenai tempat tersebut, tapi akan menjadi suatu masalah yang serius jika pengalaman yang diceritakan adalah suatu hal yang negatif.

Disparbud Gresik dalam membentuk sebuah citra Pulau Bawean melalui Sail to Indonesia 2019 yaitu terlihat dengan adanya keseriusan dalam menyelenggarakan acara tersebut. Disparbud memberikan full service baik dari sisi SDM, pelayanan wisatawan, maupun suguhan konsep dan kemasan acara. Disparbud dalam membentuk sebuah citra kini memberikan sebuah pengalaman dan kenangan yang baik disegala aspeknya. Hal tersebut dilakukan dengan tujuan para wisatawan mendaparkan pengalaman yang baik yang kemudian pengalaman tersebut akan diceritakan kepada orang lain. Upaya membentuk sebuah image yang baik melalui word of mouth bisa menjadi salah satu strategi upaya untuk meningkatkan jumlah kunjungan wisatawan yang sudah terbukti kebenarannya oleh orang yang menceritakan pengalamannya. (Murfianti, 2010) mengatakan bahwa event marketing dapat memproduksi "symbolic goods" berupa ide, pengalaman, dan image yang dapat mengkontruksi sebuah image yang baik bagi sebuah kota. Adanya event Sail to Indonesia 2019 di Pulau Bawean bisa menjadi "symbolic goods" bagi Pulau Bawean serta meningkatkan peran sebagai strategi fortifikasi Pulau Bawean seperti yang dikatakan (Satriya, 2014) bahwa sebuah event marketing mempunyai peran sebagai strategi fortifikasi yang bertujuan untuk menghubungkan dan memperkuat citra sebuah tempat.

\section{Sail to Indonesia 2019 Di Pulau Bawean Sebagai Upaya Meningkatkan Kunjungan Wisatawan}

Upaya Sail to Indonesia 2019 di Pulau Bawean dalam meningkatkan kunjungan wisatawan yaitu dengan membentuk sebuah image Pulau Bawean yang baik. Pembentukan image yang baik selama Sail to Indonesia 2019 di Pulau Bawean bisa dijadikan sebuah alasan untuk meningkatkan keloyalitasan para wisatawan untuk datang kembali ke Pulau Bawean melalui current image. Image tersebut dijadikan current image atau citra kini bagi wisatawan nantinya melalui word of mouth, yaitu dengan menceritakan pengalaman terbaiknya selama di Pulau Bawean kepada orang lain dan kemudian mengajaknya untuk datang ke Pulau Bawean. Word of mouth marketing kini tidak hanya bisa dilakukan secara langsung face to face saja namun juga bisa dilakukan melalui teknologi seperti penggunaan sosial media. Penggunaan word of mouth dapat mempengaruhi orang lain karena word of mouth identik dengan review positif seseorang yang telah mendapatkan pengalaman terbaik.

Upaya yang dilakukan oleh Disparbud Gresik tersebut sesuai dengan bauran komunikasi personal selling dimana dengan mempersuasi para wisatawan langsung dengan menjamu dan memberikan layanan yang baik selama penyelenggaraan acara berlangsung. Dengan memberikan pelayanan terbaik akan mempersuasi dan membujuk wisatawan untuk datang kembali ke Pulau Bawean dan menceritakan pengalaman terbaiknya. Seperti yang dikatakan Kusniadji (2018) bahwa keistimewaan komunikasi personal selling terletak pada kemampuannya untuk berinteraksi secara langsung untuk mengimprovisasi proses penjualan melalui komunikasi person to person.

Sail to Indonesia 2019 di Pulau Bawean bisa menjadi representasi branding Pulau Bawean untuk dikenalkan kepada para wisatawan dan calon wisatawan untuk meningkakan branding wisata Pulau Bawean yang akan dapat meningkatkan perekonomian masyarakat. Hal tersebut sesuai dengan penelitian yang berjudul “City Branding Sawahlunto Kota Wisata Tambang Yang 
Berbudaya Melalui Event Sawahlunto International Songket Carnival (Sisca) 2016" yang ditulis oleh (Fajrini et al., 2018). Berdasarkan hasil penelitian bahwa melalui event pariwisata SISCa 2016 bisa menjadikan representasi city branding Sawahlunto sebagai kota wisata tambang yang berbudaya yang dapat meningkatkan branding songket Silungkang yang ada di Sawahlunto serta bisa memberikan dampak positif pada perekonomian masyarakat melalui peningkatan omset dan perluasan pasar songket Silungkang. Relevansi dengan penelitian ini yaitu event Sail to Indonesia 2019 di Pulau Bawean bisa menjadi representasi city branding Pulau Bawean yang bisa meningkatkan branding wisata Pulau Bawean serta dapat meningkatkan perekonomian masyarakat.

\section{KESIMPULAN}

Pemerintah Kabupaten Gresik bersama para stakeholders dalam membentuk image Pulau Bawean melalui event pariwisata Sail to Indonesia 2019 tidak hanya menerapkan unsur teori keunikan event menurut Donald Getz. Pemerintah Kabupaten Gresik dalam membentuk sebuah image Pulau Bawean, selain menerapkan unsur hospitality, symboliysm. authenticity, theming, dan festive spirit juga terdapat unsur convinience (kenyamanan) yang dibuktikan dengan pemenuhan semua kebutuhan para wisatawan selama kegiatan berlangsung yang dikhususkan untuk acara Sail to Indonesia 2019 serta turut mengajak para wisatawan untuk aktif dan menjadi bagIAn acara tersebut sehingga tidak hanya menjadi penonton pasif selama acara berlagsung.

Upaya pemerintah Kabupaten Gresik bersama stakeholders dalam meningkatkan kunjungan wisatawan yaitu dengan menggunakan wish image untuk memaksimalkan harapan terhadap Pulau Bawean sehingga memberikan pelayanan terbaik selama kegiatan berlangsung. Selain itu, melalui current image para wisatawan akan menceritakan semua pengalaman dan kenangan terbaiknya selama di Pulau Bawean dengan word of mouth marketing. Word of mouth dapat mempengaruhi orang lain karena word of mouth identik dengan review positif seseorang yang telah mendapatkan pengalaman terbaik. Word of mouth marketing dapat dilakukan oleh para wisatawan yang telah mendapatkan pengalaman terbaik dengan menceritakan secara langsung face to face atau menggunakan teknologi seperti bercerita di sosial media.

\section{DAFTAR PUSTAKA}

Astuti, W. P., \& Kusumawati, A. (2018). Upaya Pemasaran Pariwisata Ponorogo Melalui City Branding dalam Meningkatkan Kunjungan Wisatawan ( Studi Kasus pada City Branding Kabupaten Ponorogo dengan Tagline "Ethnic Art of Java " ). Jurnal Administrasi Binis, 55(1), 48-58.

Aurellia Frida. (2014). Komunikasi Interpersonal Antara Pelanggan Dengan Calon Pelanggan Dalam Merekomendasikan Event Organizer. Jurnal E-Komunikasi Program Studi Ilmu Komunikasi Universitas Kristen Petra, Surabaya, 2(14), 10.

Bowdin, G. (2011). Events Management. Routledge.

Bungin, B. (2015). Komunikasi pariwisata (tourism communication): Pemasaran dan brand destinasi. Jakarta: Prenadamedia Group.

Donalds Getz, S. J. P. (2016). Progress And Prospects For Event Tourism Research. Tourism Management, 52(1), 593-631.

Effendy, O. U. (2007). Pengantar Ilmu Komunikasi. Jakarta: CV. Remaja Rosdakarya.

Fajrini, N., Bakti, I., \& Novianti, E. (2018). City Branding Sawahlunto Kota Wisata Tambang Yang Berbudaya Melalui Event Sawahlunto International Songket Carnival (Sisca) 2016. PRofesi Humas : Jurnal Ilmiah Ilmu Hubungan Masyarakat, 2(2), 169. 
Jani, N. P. (2016). Pengaruh Event Terhadap Pengambilan Keputusan Berkunjung Ke Anjungan Jawa Timur - Taman Mini Indonesia Indah Program Studi Industri Perjalanan. In STPB Repository.

Kusniadji, S. (2018). Kontribusi Penggunaan Personal Selling Dalam Kegiatan Komunikasi Pemasaran Pada Era Pemasaran Masa Kini. Jurnal Komunikasi, 9(2), 176-183.

Lestari, A. A., Waluya, B., \& Andari, R. (2017). Pengaruh Culture Event di Anjungan Bengkulu Taman Mini Indonesia Indah Jakarta Terhadap Citra Destinasi Wisata Provinsi Bengkulu. THE Journal : Tourism and Hospitality Essentials Journal, 7(2), 113.

Murfianti, F. (2010). Membangun City Branding Melalui Solo Batik Carnival. In Asintya (Vol. 2, Issue 1, pp. 105-118).

Ningsih, F. E. (2019). Upaya Dinas Kebudayaan Dan Pariwisata Dalam Meningkatkan Jumlah Kunjungan Wisatawan (Studi Pada Dinas Kebudayaan, Pariwisata, Pemuda Dan Olahraga Kabupaten Sumenep). Jurnal Administrasi Bisnis (JAB), 70(1), 61-72.

Pakarti, S., Andriani, K., \& Mawardi, kholid m. (2017). Pengaruh City Branding Dan Event Pariwisata Terhadap Keputusan Berkunjung Serta Dampaknya Pada Minat Berkunjung Kembali Ke Kabupaten Banyuwangi. Jurnal Administrasi Bisnis S1 Universitas Brawijaya, 47(1).

Pendit, N. S. (2006). Ilmu Pariwisata Sebuah Pengantar Perdana. Edisi Terbaru.

Satriya, C. Y. (2014). Kontribusi Event Marketing Terhadap Ekuitas Merek Kota Solo. Jurnal Ilmiah Komunikasi Makna, 5(1), 42. https://doi.org/10.30659/jikm.5.1.42-53 